\title{
Chronic renal failure in equine due to ascending pyelonephritis predisposed by cauda equina syndrome: Case report
}

\author{
[Insuficiência renal crônica em equino devido à pielonefrite ascendente predisposta por \\ síndrome da cauda equina: Relato de caso] \\ J.H. Fonteque ${ }^{1}$, M.C.S. Granella ${ }^{2}$, A.F. Souza ${ }^{2}$, R.P. Mendes ${ }^{2}$, J. Schade ${ }^{3}$, V. Borelli ${ }^{1}$,

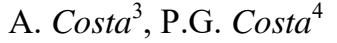 \\ ${ }^{1}$ Universidade do Estado de Santa Catarina - Lages, SC \\ ${ }^{2}$ Aluno de graduação - Universidade do Estado de Santa Catarina - Lages, SC \\ ${ }^{3}$ Aluno de pós-graduação - Universidade do Estado de Santa Catarina - Lages, SC \\ ${ }^{4}$ Médica veterinária autônoma - Curitibanos, SC
}

\begin{abstract}
This report describes the case of a mare, of the Campeiro breed, used as an embryo donor, which had recurrent cystitis and urinary incontinence crisis. Clinical signs evolved to progressive weight loss, anorexia, apathy, and isolation from the group. Physical examination showed tail hypotonia, perineal hypalgesia, rectal and bladder sagging compatible with signs related to cauda equina syndrome. Complementary laboratory and sonographic assessment, and necropsy confirmed the diagnosis of chronic renal failure (CRF), which was attributed to the ascending pyelonephritis. The examination of urine culture showed growth of bacteria of the genus Streptococcus sp. This is a rare case in the equine species where the lower motor neuron dysfunction led the development of infectious process in the urinary tract, progressing to renal chronic condition incompatible with life.
\end{abstract}

Keywords: Campeiro, nephropathy, neuropathy, urinary tract.

\section{RESUMO}

Descreve-se o caso de uma égua, da raça Campeiro, utilizada como doadora de embriões, que apresentava quadros de cistite recorrente e incontinência urinária. Os sinais clínicos evoluíram para emagrecimento progressivo, anorexia, apatia e isolamento do plantel. Ao exame físico, foi identificada hipotonia da cauda, hipoalgesia da região perineal, flacidez retal e vesical, compatíveis com sinais relacionados à síndrome da cauda equina. Exames complementares laboratoriais, exame ultrassonográfico e necropsia confirmaram o diagnóstico de insuficiência renal crônica (IRC), a qual foi atribuida à pielonefrite ascendente. $O$ exame de urocultura demonstrou crescimento de bactérias do gênero Streptococcus sp. Este é um caso raro em equinos em que a disfunção de neurônio motor inferior propiciou o desenvolvimento de processo infeccioso no trato urinário, progredindo para um quadro crônico renal incompatível com a vida.

Palavras-chave: Campeiro, nefropatia, neuropatia, trato urinário

\section{INTRODUTION}

Cauda equina syndrome (CES) is a neurological disorder secondary to traumatic, metabolic, infectious, inflammatory, toxic, and/or degenerative alterations characterized by clinical manifestations related to lower motor neuron (LMN) injury (Hines, 2015; Sponseller, 2015).

Recebido em 22 de abril de 2017

Aceito em 5 de agosto de 2017

* Autor para correspondência (corresponding author)

E-mail: milenacarolsgranella@gmail.com
The cauda equina corresponds to the nerve ramifications of the incongruity between the segments of the spinal cord and the spinal canal, being located caudally to the lumbosacral junction (Nout and Jeffcott, 2013; Hines, 2015).

Injuries in this region provide LMN signals, characterized by flaccid paralysis, bladder, rectal and urethral sphincters atony. The main 
complications established after cauda equina injury are related to the organs of the urinary tract, due to predispose bladder and kidney ascending infections, leading to cystitis and pyelonephritis, respectively, affecting organs functionality, and can result in chronic renal failure. (Schott, 2007; Dyce et al., 2010; Schott, 2010).

Due to the infrequent clinical presentation of upper urinary tract changes resulting from neurological disorders, the objective is to describe the case of an equine with chronic renal failure secondary to pyelonephritis due to ascending infection of the urinary tract, which was predisposed by cauda equina syndrome, occurred in Lages city, Santa Catarina state, Brazil.

\section{CASUISTRY}

An equine, female, Campeiro breed, 15 years old, weighing $400 \mathrm{~kg}$, used as an embryo donor, underwent medical examination at the Hospital de Clínica Veterinária (HCV) of Centro de Ciências Agroveterinárias (CAV) of
Universidade do Estado de Santa Catarina (UDESC), Lages-SC, Brazil.

According to the clinical history, since it was acquired a year before presentation, the animal had urinary incontinence and recurrent episodes of cystitis, evolving into progressive weight loss, anorexia, apathy, reluctance to move and isolation from the group. No changes were observed on physical examination in vital parameters, however, rectal temperature did not provide reliable information due to anal sphincter relaxation and consequent air within it. The animal was lethargic, in standing position and nutritional status was considered thin (Figure 1). The mucous membranes were pink and uremic breath was evidenced during the inspection of the oral cavity. The abdominal auscultation revealed hypomotility in the four quadrants. Neurological examination showed incoordination characterized by ataxia and hind limbs paresis, tail hypotonia, perianal region hypoalgesia, anal sphincter relaxation and urinary incontinence. Rectal palpation showed distended rectum by air (pneumorectum) with few feces retention, bladder sagging and no changes in the caudal edge of the left kidney.

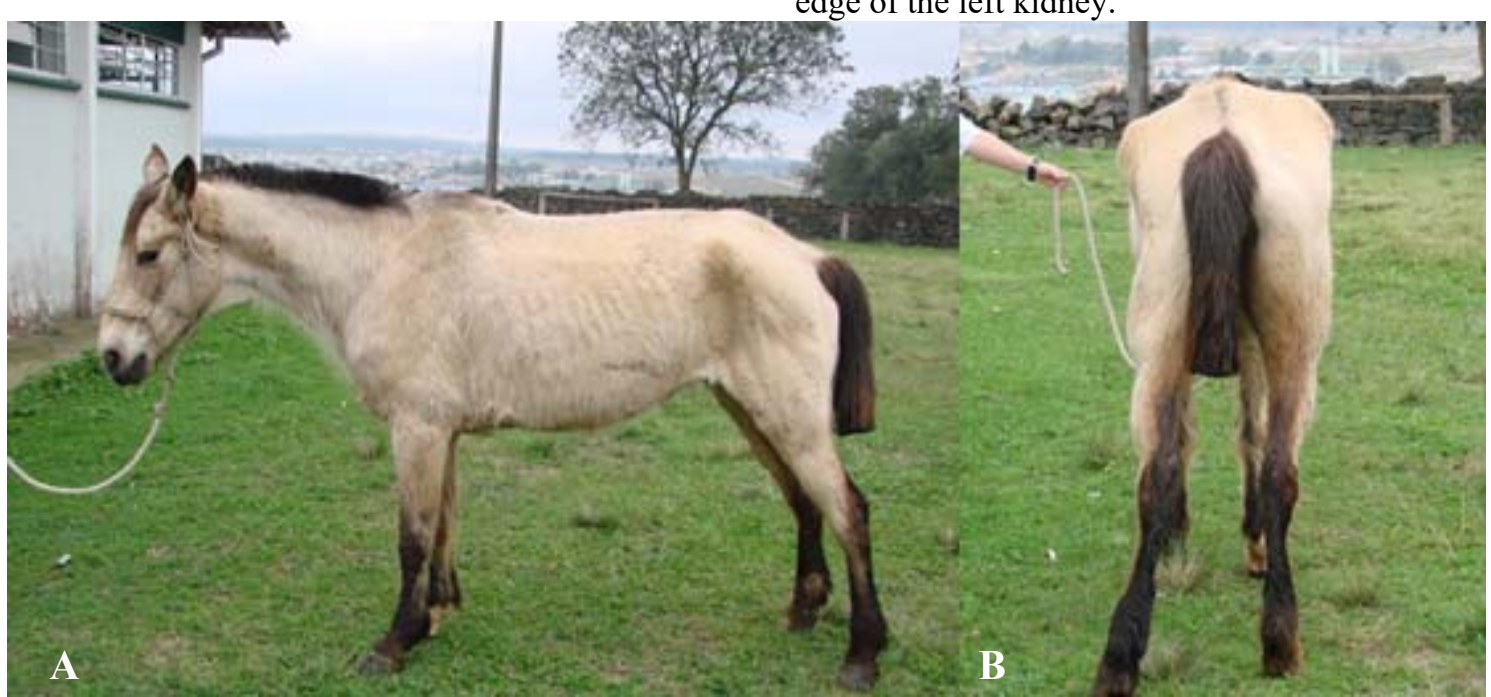

Figure 1. Equine, female, Campeiro breed, 15 years old, with chronic renal failure due to ascending pyelonephritis predisposed by cauda equina syndrome showig evident ribs and posture (1. A.) and evidence of coxal tuberosity, in a caudal view, characteristics of animal with lean nutritional status.

Laboratory tests were performed on the first day and revealed hemoconcentration (first day), anemia (following analyzes), neutrophilia leukocytosis, hyperproteinemia, hyperfibrinogenemia, azotemia, hypoalbuminemia, and hyperglobulinemia (Table 1). Urinalysis (collection by natural urination) revealed isostenuria (1.011), pyuria (leukocytes/field: 80120 with two crosses of bacteria), proteinuria (two crosses), neutral $\mathrm{pH}$ and presence of several leukocyte clusters, renal and vesical desquamation cells and large quantity of 
sediment in the sample (Figure 2). The microbiological examination allowed, through uroculture, the isolation of bacteria of the genus Streptococcus sp. Ultrasound examination revealed a reduction of parenchymal thickness and multiple hyperechoic points distributed through the cortical layer of both kidneys.

Table 1. Values for complete blood cells and serum biochemistry tests performed on the first, fifth and eighth day of hospitalization of a female horse with chronic renal failure secondary to pyelonephritis

\begin{tabular}{llll}
\hline Exams & First day & Fifth day & Eighth day \\
\hline Eritrogram & 6,43 & 5,52 & 5,38 \\
RBC $\left(\mathrm{x} 10^{6} / \mu \mathrm{L}\right)$ & 32 & 21 & 23 \\
PCV $(\%)$ & 11,6 & 7,6 & 8,0 \\
Hemoglobin $(\mathrm{g} / \mathrm{dL})$ & 49,8 & 38,0 & 42,8 \\
MCV $(\mathrm{fL})$ & 36,3 & 36,2 & 34,8 \\
MCHC $(\%)$ & 396 & 102 & 117 \\
Platelets $\left(\mathrm{x} 10^{3} / \mu \mathrm{L}\right)$ & 10,8 & 10,3 & 11,1 \\
TPP $(\mathrm{g} / \mathrm{dL})$ & 800 & 600 & 500 \\
Fibrinogen $(\mathrm{mg} / \mathrm{dL})$ & & & 14.330 \\
Leucogram & 24.850 & 13.410 & 11.034 \\
WBC $\left(\mathrm{x} 10^{3} / \mu \mathrm{L}\right)$ & 21.868 & 11.130 & 2.436 \\
Neutrophils $\left(\mathrm{x} 10^{3} / \mu \mathrm{L}\right)$ & 2.485 & 1.207 & 573 \\
Lymphocytes $\left(\mathrm{x} 10^{3} / \mu \mathrm{L}\right)$ & 497 & 134 & 287 \\
Monocytes $(/ \mu \mathrm{L})$ & 0 & 939 & 0 \\
Eosinophils $(/ \mu \mathrm{L})$ & 0 & 0 & 244,10 \\
Basophils $(/ \mu \mathrm{L})$ & & & 3,87 \\
Serum biochemistry & 352,18 & 207,03 & 10,73 \\
Urea $(\mathrm{mg} / \mathrm{dL})$ & 6,73 & 3,70 & 1,70 \\
Creatinine $(\mathrm{mg} / \mathrm{dL})$ & 10,06 & 9,80 & 9,03 \\
Total serum protein $(\mathrm{mg} / \mathrm{dL})$ & 2,00 & 2,45 & \\
Albumin $(\mathrm{mg} / \mathrm{dL})$ & 8,06 & 7,35 & \\
Globulin $(\mathrm{mg} / \mathrm{dL})$ & & & \\
\hline
\end{tabular}

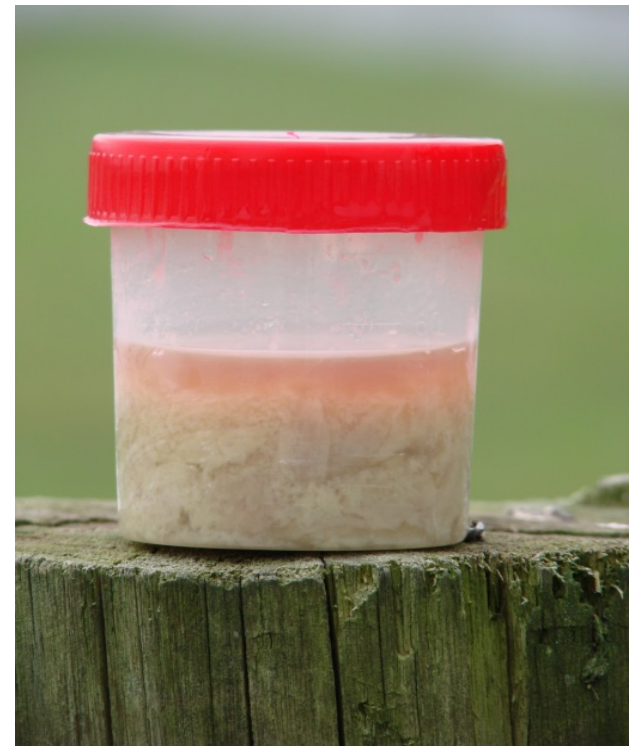

Figure 2. Urine of cloudy appearance and presence of thick lump sediment collected by spontaneous urination, representing infectious process.
Treatment included electrolyte replacement with $0.9 \%$ sodium chloride intravenously (IV), totaling 180 liters, of these, 40 liters administered on the first day and another 20 liters for daily maintenance for seven days. A diuretic (furosemide) $4 \mathrm{mg} / \mathrm{kg}$, IV, SID was also used for two days. Associated with penicillin benzathine antibiotic therapy $30.000 \mathrm{IU} / \mathrm{kg}$, IM, every 48 hours for six days.

There was improvement in the clinical condition after the beginning of the treatment, characterized by return of the appetite and alert mental state. However, due to the irreversibility of the animal's condition and the unfavorable prognosis, euthanasia was indicated and proceeded with the consent of the owner.

At necropsy, the left kidney was reduced in size and was evidenced through the cut, purulent exudate and absence of the cortical and medullary layers. The right kidney was enlarged and absent from the medullary layer and purulent 
exudate was evident through the cut (Figure 3). No alterations compatible with trauma, neoformation or stenosis were observed in the lumbosacral region of the spine. No alterations were observed in the other organs either. The bladder and ureters musculature were thickened, containing yellow, turbid-looking urine inside.
Histopathological examination revealed the kidneys with intense corticomedullary degeneration characterized by the marked multifocal infiltration of neutrophils, diffuse interstitial macrophages and thickening of Bowman's capsule.

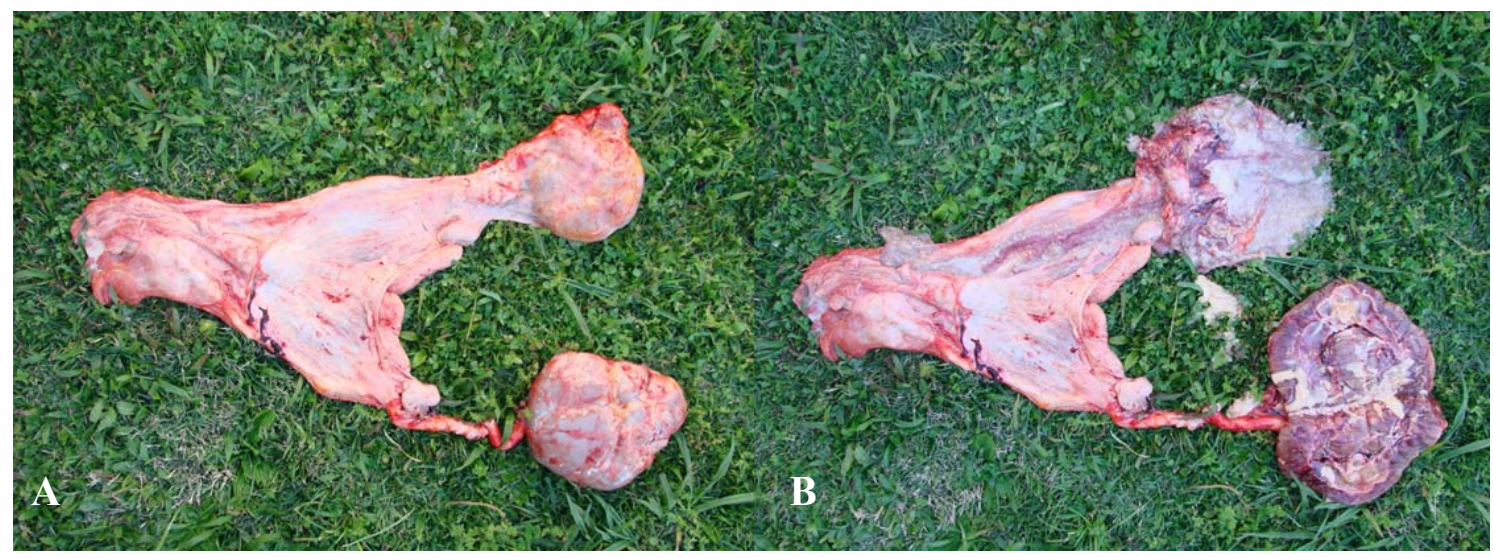

Figure 3. Urinary tract organs of an equine female with chronic renal failure due to cystitis and ascending pyelonephritis. A) Reduced left kidney and increased right kidney in size, with thickening of the ureters. B) Kidneys with purulent exudate.

The diagnosis of chronic renal failure was established, which was attributed to ascending bacterial pyelonephritis, predisposed by the cauda equina syndrome, in which primary cause cannot be determined.

\section{DISCUSSION}

Primary and/or secondary disorders of the renal functions in equines are rare and can be attributed to the fact that this species has a greater number of nephrons than other mammals, favoring compensatory mechanisms (Schott, 2007; Toribio, 2007; Schott, 2010), which may justify the long period of evolution of the reported picture.

According to Toribio (2007), Budras et al. (2009) and Dyce et al. (2010), renal physiology is coordinated by sympathetic and parasympathetic autonomic innervation along somatic branches of the central nervous system (CNS). Budras et al. (2009) afirm that the coordination of the tonicity of the sphincter muscles and adjacent organs are performed by the LMN, which is responsible for interconnecting the CNS to the effector organ, so dysfunctions in these nerve conduction pathways result in neurogenic urinary incontinence (Hines, 2015; Sponseller, 2015).

The affection of the LMN in the case described is related to the CES, evidenced by signs of motor incoordination characterized by ataxia and paresis of the pelvic limbs, tail hypotonia, hypoalgesia of the perianal region, relaxation of the anal sphincter and pneumorectum observed in the physical examination. According to Hines (2015), motor incoordination and muscular atrophy of the pelvic limbs are uncommon, but may be observed along with signs of CES if the spinal cord affection extends cranially to the cauda equina.

Among the causes of CES, the most frequently reported causes are equine herpesvirus type 1 (EHV-1) encephalomyelopathy, equine protozoal myeloencephalitis (EPM), equine tail polyneuritis, degenerative myeloencephalopathy, sacral and spinal traumas, sorghum intoxication and neoplasms (Schott, 2010; Hines, 2015; Sponseller, 2015). However, in the present description the cause of the CES could not be determined due to the lack of information from the previous owner, since the animal was acquired already under this condition. 
The bacterial cystitis and pyelonephritis observed in the case come from the atony of the sphincters, which allowed the upward migration of the microorganisms to the upper portions of the urinary tract, considering that this is the most frequent route of the infections described in this system (Kunin, 1994). The isolated bacteria were Streptococcus sp., which according to Newman (2012), is the most commonly agent involved.

Another secondary condition that could be associated with the animal's clinical condition is idiopathic bladder paralysis (sabulous urolithiasis). It is described as the presence of abnormal amounts of crystalloid sediments within the bladder resulting from detrusor muscle dysfunction, since incomplete emptying of the organ occurs during urination (Schott, 2010; Newman, 2012).

In the case described, cystitis is diagnosed due to the neurogenic disorder involved in urinary incontinence, accompanied by ascending infection, and consequently, urinary vesicle mucosa constant irritation and accumulation of sediment, characterizing sabulous cystitis according to Rendle et al. (2008).

Anemia may be associated with the low body condition and with renal parenchymal degeneration, which interferes with erythropoiesis, since erythropoietin is insufficient or absent (Alpers, 2005).

The results of the serum biochemical tests confirmed the uremia, where urea and creatinine concentrations decreased after hydration. However, they remained elevated on the fifth and eighth day, demonstrating pre-renal and renal azotemia (Grossman et al., 1982; Schott, 2007). Isostenuria reflected the inability of the urine to concentrate. These alterations associated to the intense corticomedullar degeneration observed in histopathology confirmed the CRF (Alpers, 2005; Toribio, 2007; Schott, 2010; Newman, 2012).

The treatment protocols for urinary vesicle dysfunction consist, regardless of etiology, in the stimulation of emptying and development of neurological reflexes (Rendle et al., 2008). However, the longer the progression time, the greater the consequences involved and the greater the chances of ineffective treatment.
Antimicrobial therapy to treat secondary cystitis would have been more effective if it had been performed earlier, since at the stage in which the animal was, with renal parenchyma destruction and extensive involvement of the urinary tract organs, therapeutic strategy was inefficient, although the animal showed an improvement.

Other diagnostic methods for evaluation of renal function include biopsy and ultrasonography, which is the technique of choice to provide information on renal dimensions and structures, allowing for the confirmation of CRF (Schott, 2007; Schott 2010; Newman, 2012; Hines, 2015; Sponseller, 2015).

Animals that manifest CES due to the repercussion of the disease must be monitored since there can be compromising of vital organs and result in intense and irreversible lesions, especially in the urinary tract, as in the case reported. In this way, the importance of the interference of conscious professionals who are careful to avoid the progression of the ascending infection, as well as, to associate effective treatments to prevent CRF is reinforced.

\section{CONCLUSIONS}

Although rare in equines, dysfunctions associated with the cauda equina predisposes the ascending infections of the urinary system. Thus, early clinical interventions are recommended in order to obtain a better prognosis.

\section{REFERENCES}

ALPERS, C.E. O rim. In: KUMAR, V.; ABBAS, A.K.; FAUSTO, N. (Eds.). Robbins e Cotran patologia - bases patológicas das doenças. 6.ed. Rio de Janeiro: Elsevier, 2005. p.999-1066.

BUDRAS, K.; SACK, W.O.; RÖCK, S. Anatomy of the horse: an illustrated text. 5.ed. Hannover: Schlütersche, 2009. 199p.

DYCE, K.M.; SACK, W.O; WENSING, C.J.G. The neck, back and vertebral column of the dog and cat - veterinary anatomy. 4.ed. Missouri: Saunders Elsevier, 2010. p.407-419.

GROSSMAN, B.S.; KRAMER J.W.; BAYLY W.M. et al. Urinary indices for differentiation of prerenal azotemia and renal azotemia in horses. J. Am. Vet. Med. A., v.180, p.284, 1982. 
HINES, M. Differential diagnosis of urinary incontinence and cauda equina syndrome. In: FURR, M.; REED, S. Equine neurology. 2.ed. Iowa: Blackwell Publishing, 2015. p.139-148.

KUNIN, C.M. Urinary tract infections in females. Clin. Infect. Dis., v.18, p.1-10, 1994.

NEWMAN, S.J. The urinary system. In: ZACHARY, J.F.; MCGAVIN, M.D. (Eds.). Pathologic basis of veterinary disease. 5.ed. Missouri: Elsevier Mosby, 2012. p.589-658.

NOUT, Y.S.; JEFFCOTT, L.B. Neurology. In: MAIR, T.; LOVE, S.; SCHUMACHER, J. et al. Equine medicine, surgery and reproduction. 2.ed. Philadelphia: Saunders Elsevier, 2013. p.211-234.

RENDLE, D.I.; DURHAM, A.E.; HUGHES, K.J. et al. Long-term management of sabulous cystitis in five horses. Vet. Rec., v.162, p.783787, 2008.
SCHOTT, H.C. Chronic renal failure in horses. Vet. Clin. N. Am. Equine Pract., v.23, p.593-612, 2007.

SCHOTT, H.C. Disorders of the urinary system. In: REED, S.M.; BAYLY, W.M.; SELLON, D.C. (Eds.). Equine internal medicine. 3.ed. Saint Louis: Saunders Elsevier, 2010. p.11711296.

SPONSELLER, B.T. Urinary incontinence. In: SPRAYBERRY, K.A.; ROBINSON, N.E. (Eds.). Robinson's current therapy in equine medicine. 7.ed. Saint Louis: Elsevier, 2015. p.443-444.

TORIBIO, R.E. Essentials of equine renal and urinary tract physiology. Vet. Clin. N. Am. Equine Pract., v.23, p.533-561, 2007. 